\title{
Vol. 21 Editor's Note
}

\section{Rachel Leket-Mor \\ Arizona State University Library}

Dear readers,

Welcome to a new volume on a new platform, opening a new chapter in the history of Judaica Librarianship!

In 2013, after having been published in print for thirty years, Judaica Librarianship (JL) became an electronic publication. This significant development was accompanied by a momentous decision to open the journal's content to all readers after a 12-month period of exclusive access to association members. These changes broadened the journal's readership - there were over 41,000 downloads in the past five years - and resulted in a threefold increase in the article citation rate. The editorial board did not need any further convincing when it decided last year to move to full open access publishing. Volume 21 is the first completely open issue as well as the first to be published on the Open Journal Systems (OJS) platform of the Public Knowledge Project (PKP). On behalf of the Association of Jewish Libraries (AJL), I welcome all readers to this inaugural volume, which strengthens AJL's mission to promote Jewish literacy and foster access to information, learning, teaching, and research relating to Jews, Judaism, the Jewish experience, and Israel.

Our new site's cleaner look, greater flexibility, and novel functionalities are welcome byproducts of the separation from the Bepress-hosted Digital Commons platform. In 2017, Bepress was abruptly acquired by Elsevier, the behemoth for-profit publisher. ${ }^{1}$ This impelled AJL to search for a new home for our online journal not only to maintain the financial health of our non-profit organization, which relies on a community of volunteer professionals for its operation, but also to advance our commitment as librarians to the free exchange of information in general and of scholarly communication in particular.

Even with the experience gained through the previous transformation of JL and with developments in digital publishing over the past seven years, setting up the new OJS partnership was an exacting and time-consuming endeavor. It is my pleasure to thank those who helped me along the way. Lars Vilhuber, managing editor of the Journal of Privacy and Confidentiality, was kind enough to share his experience in making a recent transition from Bepress to OJS (see also his published essay). ${ }^{2}$ My son Omri Mor wrote a Python script to automate the addition of missing

\footnotetext{
${ }^{1}$ See Roger C. Schonfeld, “Elsevier Acquires bepress,” The Scholarly Kitchen (blog), August 2, 2017, https://scholarlykitchen.sspnet.org/2017/08/02/elsevier-acquires-bepress.

${ }^{2}$ Vilhuber, Lars. "Relaunching the Journal of Privacy and Confidentiality." Journal of Privacy and Confidentiality 8, no. 3 (2018). https://doi.org/10.29012/jpc.706.
} 
DOIs to our XML files before migrating the Bepress-published articles to OJS. The wonderful team at PKP — Michael Felczak, Mariya Maistrovskaya, Mike Nason, and Jason Nugent—spent hours communicating with me to reconfigure JL's domain and Cross-Ref accounts, custom-design our new site, and migrate our content. I wholeheartedly thank Michael Cobb of Bepress, who provided years of excellent support for JL on our previous platform. I thank my family for the many sacrifices they made in allowing me to successfully navigate this journal through this critical juncture. I also thank my colleagues at ASU Library - most notably my unit head Shari Laster-for their continued encouragement. A big thank-you is due to AJL's board and council, which unanimously approved the proposal to switch providers and move to open access publishing. Last but not least, I am indebted to the thoughtful counseling of JL's editorial board members: mori ye-rabi Zachary Baker, Annette Goldsmith, Rachel Heuberger, Rebecca Jefferson, Arthur Kiron, Roger Kohn, and Jim Rosenbloom.

Now, to volume 21. Archives are at the heart of all the collections-related articles and emerge as one of the three major themes in this issue.

Gabriel Mordoch and Melanie Hubbard recount chance discoveries in their institutional collections (University of Michigan and Loyola Marymount University, respectively) and raise compelling arguments against the silos that separate librarians according to the types of service they provide. Mordoch develops this postulation even further with a scholarly exploration of the role of catalogers with respect to special collections materials. Through the presentation of their respective archival collections, Max Daniel (UCLA) and Jeanne Abrams (University of Denver) provide expansive views of local Jewish communities in the Western United States, and Hubbard offers readers a glimpse into the refugee Jewish community of Shanghai during World War II. The latter three authors also report on their outreach programs: Hubbard describes how crowdsourcing was brought into play to enhance the metadata of items in the Werner Von Boltenstern Shanghai Photograph and Negative Collection. Abrams demonstrates the pedagogical use of primary sources from the Beck Archives in undergraduate education at the University of Denver Libraries. Daniel writes about the UCLA Sephardic Archive Initiative, which created a Sephardic "Antique Roadshow" and recently launched the Sephardic Los Angeles online portal.

Sephardic identities and collections constitute the second theme of this issue. ${ }^{3}$ Sephardim are Jews who trace their family roots to Spain during the Islamic al-Andalus era (identified in Hebrew with the biblical Sepharad) whence they were expelled in 1492 to rebuild communities throughout the Mediterranean, the Ottoman Empire and the Americas. Their cultural heritage, associated with a rich body of philosophy, literature, and musical works in Hebrew, Ladino (Judeo-Spanish), Judeo-Arabic, and other languages, has not been systematically collected, especially in American institutions. Max Daniel describes the process of compiling and arranging

${ }^{3}$ The cover art features this theme with the first issue of NASAWI News (1997), a magazine of the New Association of Sephardi/Mizrahi Artists \& Writers International. 
a community archival collection of the Sephardic Temple Tifereth Israel in Los Angeles, now at UCLA. The life story of Victor Perera, who donated his papers and library to the University of Michigan Library, is unfolded in Gabriel Mordoch's paper. Perera's fictional works and political manifestos celebrate his Sephardic identity. These two important collections join other online projects on Sephardic culture such as Sephardic Voices (oral histories in English and interviews in Judeo-Arabic $)^{4}$ and the Piyyut and Prayer collaborative site at the National Library of Israel. ${ }^{5}$ It is hoped that shedding light on these collections will advance the field of Sephardic studies.

A third theme of the current issue is the Sydney Taylor Book Award (STBA), which celebrated its fiftieth anniversary in 2018. Companion articles contemplate the history and nature of this award in theoretical terms (Anastasia Collins) and with visual tools (Fred Isaac and Rachel Leket-Mor) and invite the readers to explore how the award has both reinforced and challenged the tendency to reduce Jewish history to the horrors of the Holocaust.

Michelle Martin's tribute allows us to commemorate June Cummins, who passed just before the 2018 celebration. Cummins, an acclaimed scholar of children's literature, wrote the forward for the 2014 edition of Taylor's All-Of-A-Kind Family (Lizzie Skurnick Books) and authored a book-length manuscript about the series. ${ }^{6}$ Cummins also served as a reviewer for Judaica Librarianship and her loss is deeply felt.

Our community lost another long-time JL contributor in 2019, with the passing of Leah Adler of Yeshiva University Libraries. Leah, who was well-loved by all as is evident in Pearl Berger's tribute, served on the AJL board and council, and contributed her time and remarkable skill to index many of the journal's back issues before full-text searching became possible and available (JL volumes 8-20 and Leah's indexes are found on the Archives section of our site).

Some of the Sydney Taylor Book Award winners, along with other children's books, are featured in this volume in the "Love Your Neighbor" essay (Heidi Rabinowitz and Kathleen Bloomfield). In these dark times, the AJL project to combat antisemitism with books as educational resources is too important to get lost on the web. We decided to reprint these librarian-recommended book lists from the AJL website, along with the accompanying essay, to affirm our association's commitment to fight prejudice, hate, and racism in all forms.

\footnotetext{
${ }^{4}$ This project "gives voice to the one million Jews who were uprooted from their homes, neighborhoods, and ancestry in North Africa, the Middle East, and Iran;” https://sephardivoices.com/about-us/, accessed March 15, 2020.

5 This site preserves thousands of songs, prayers, and piyyutim performances from across the world: https://web.nli. org.il/sites/nlis/he/song/Pages/about-.aspx, accessed March 30, 2020.

${ }^{6}$ Cummins, June. "Becoming an 'All-of-a-Kind' American: Sydney Taylor and Strategies of Assimilation." The Lion and the Unicorn 27, no. 3 (2003), 324-343; Cummins, June. "Leaning Left: Progressive Politics in Sydney Taylor's All-of-a-Kind Family Series." Children's Literature Association Quarterly, vol. 30, no. 4 (2005), 386408; Cummins, June. Introduction to All-Of-A-Kind Family, by Sydney Taylor (New York: Lizzie Skurnick Books, 2014); Cummins, June. "From Sarah to Sydney: The Woman behind "All-of-a-Kind Family" (unpublished manuscript, 2018).
} 
Our columnists Haim Gottschalk and Michelle Chesner contributed, respectively, the 2020 Scatter of the Literature survey (scholarly publications related to our field of Jewish libraries) and the JS/DH review of Jewish studies projects aided by digital humanities tools.

Finally, I would like to add a last note of gratitude: The platform switch and relaunch, my 2018 sabbatical, and pressing projects related to the reopening of Hayden Library at Arizona State University, where my day job is, all conspired to delay the publication of volume 21 . The journal is produced entirely by volunteers and I am grateful to the authors and anonymous peer reviewers for their hard work and patience. Special thanks go to Rebecca Jefferson for her assistance in editing, and to copyeditor Nancy Sack.

Yours,

Rachel Leket-Mor

Editor, Judaica Librarianship 